\title{
Is Economic Policy Uncertainty Related to Suicide Rates? Evidence from the United States
}

\author{
Nikolaos Antonakakis ${ }^{a, b, *}$, Rangan Gupta ${ }^{c}$ \\ ${ }^{a}$ Economics and Finance Subject Group, Portsmouth Business School, University of Portsmouth, Portland \\ Street, Portsmouth, PO1 3DE, United Kingdom. \\ ${ }^{b}$ Department of Business and Management, Webster Vienna Private University, Praterstrasse 23, 1020, \\ Vienna, Austria. \\ ${ }^{c}$ Department of Economics, Faculty of Economic and Management Sciences, University of Pretoria, 0002, \\ South Africa.
}

\begin{abstract}
While it has long been recognised that periods of economic uncertainty, characterised by increased unemployment and lower economic activity, are associated with increased suicide rates, no study has examined the impact of policy-related economic uncertainty on suicide mortality. The aim of this study is to examine the relationship between economic policy uncertainty and suicide mortality in the United States over the period 1950-2013, while controlling for several other socioeconomic determinants of suicide mortality, as well as ageand gender-variations. The results of the analysis reveal that increased economic policy uncertainty is associated with increased suicide mortality of the youngest and the oldest segments of the male population in the United States, while the female population across all ages is found to be resilient to changes in economic policy uncertainty.
\end{abstract}

Keywords: United States, Economic policy uncertainty, suicide

JEL codes: E6o I31; J11; C22

\footnotetext{
*Corresponding author, phone: (UK) +44 (0)23 9284 4261, (AT) +43 12699293 4373, fax: (UK) +44 (0)23 92844037.

Email addresses: nikolaos.antonakakis@port.ac.uk,nikolaos.antonakakis@webster.ac.at (Nikolaos Antonakakis), rangan.gupta@up.ac.za (Rangan Gupta)
} 


\section{Introduction}

It has long been recognised that periods of economic uncertainty are associated with rises in suicide (Durkheim, 1897; Morselli, 1882; Swinscow, 1951). Durkheim hypothesised that key societal forces such as social integration can be disrupted by factors related to economic downturns which consequently have an impact on suicide rates. While a large amount of studies has examined the significance of such economic factors, such as unemployment (see, e.g. Morrell et al, 1993; Platt et al, 1992; Inoue et al, 2007; Noh, 2009; Chang et al, 2010; Kuroki, 2010; Lundin et al, 2012; Garcy and Vger, 2012; Pellegrini and RodriguezMonguio, 2013; Nordt et al, 2015; Webb and Kapur, 2015; Fountoulakis et al, 2015; Dos Santos, 2015; Bonamore et al, 2015; Hsu et al, 2015; Fountoulakis et al, 2015; GoldmanMellor, 2016), income and business cycles (see, e.g. Wasserman, 1984; Ruhm, 2000; Miller et al, 2009; Gonzalez and Quast, 2010; Stuckler et al, 2011; Suhrcke and Stuckler, 2012) and fi austerity (Antonakakis and Collins, 2014, 2015; Branas et al, 2015), among others ${ }^{1}$, no study, according to our knowledge, has explored the impact of policy-related economic uncertainty perse on suicide mortality.

In this study, we fi in this gap in the literature by examining the impact of economic policy uncertainty on suicide mortality in the United States, the latter being an important indicator of a nation's overall life-satisfaction and well being, based on a recently developed measure of economic policy uncertainty by Baker et al (2015). As increased economic policy uncertainty can lead to adverse domestic macroeconomic circumstances, such as intensifying recessions and weakening recoveries (Baker et al, 2015), depressing investments (Kang et al, 2014; Wang et al, 2014), industrial production (Baker et al, 2015) and stock prices (Pástor and Veronasi, 2012), and reducing employment(Baker et al, 2015; Ferrara and Gurin, 2015), it can cause abrupt changes in the socioeconomic position of certain groups, who, becoming conscious that what has been expected can no longer be achieved, may be led to commit suicide. Indeed, when economic policy uncertainty has sizable negative side-effects, leading to greater inequalities, impoverishment and social isolation or pessimistic expectations about

\footnotetext{
'For a comprehensive survey of socioeconomic determinants of suicides see Chen et al (2012).
} 
life satisfaction in the future, suicide rates might increase namely through an emotional process associated with increased insecurity or shame of economic failure. Wethus hypothesise that changes in economic policy uncertainty are associated with suicide mortality. Moreover, we control for several other commonly used socioeconomic variables in this literature so as to account for other factor that can lead to suicide and control for potential omitted variable bias.

Our empirical results for age-standardised male and female suicide rates in the United States over the period 1950-2013, which remain robust to a battery of checks, reveal genderand age-specificities in the impact of economic policy uncertainty on suicide mortality in the United States. In particular, increases in economic policy uncertainty are associated with significant increased male suicide rates in the youngest (15-34 age group) and the oldest (65-84 age group) segments of the population, while the female population across all ages is resilient to changes in economic policy uncertainty. For the remaining socioeconomic factors of suicide mortality, the results are very much in line with the existing literature.

The rest of this paper is organised as follows. Section 2 describes the empirical methodology and the data used. Section 3 presents the empirical results and Section 4 summarises and offers some concluding remarks.

\section{Data and Methodology}

\subsection{Data}

Annual data on suicide mortalitybetween 1950 and 2010 are collected from the World Health Organisation (WHO) Mortality Database and extended up to 2013 based on the Center for Disease Control (CDC) online database, which contains annual observations for number of deaths by country, sex, age group and death cause. ${ }^{2}$ Suicide rates are measured as the number of reported deaths per 100,000 inhabitants, where population data are obtained from the WHO Mortality and CDC online databases. The economic policy uncertainty

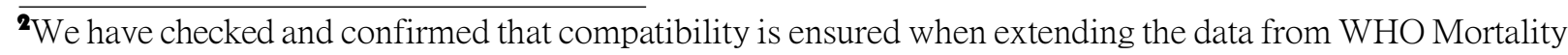
with data from the CDC database from 2010 onwards.
} 
(EPU) index, which comes from Baker et al (2015), is a news' based index of economic policy uncertainty based on article searches of leading US newspapers for terms related to economic and policy uncertainty. ${ }^{3}$ As the EPU index is available in monthly frequency, we transform it to its annual counterpart by taking the 12-month average within each year.

Figure 1 shows the evolution of suicide rates (by gender and age group) and economic policy uncertainty (EPU) form 1950 to 2013, indicating a positive correlation between the two series. In particular, EPU, as well as suicide for certain age groups among males and females, followed an increasing trend since the 1960s till the end of the 1980 . Then a declining trend is observed in both series until 2000 which was reversed since then. Further, male suicide rates are, on average, about 4 times higher than female suicide rates, which is in line with the typical observation in the sociological literature of suicide that males are more prone to committing suicide than females (Daly and Wilson, 2006; Helliwell, 2007; Chang et al, 2013). US suicide rates are also, in general, lower among younger individuals, in line with the theoretical predictions of Durkheim (1897) and the subsequent literature. Age groups 45-54, 65-74 and 75-84 years show the highest suicide mortality rates, for both men and women.

\section{[Insert Figure 1 around here]}

Finally, to control for other socioeconomic factors on suicide rates and to minimize errors arising from unobserved effects, we collect data for fertility rates from the World Bank World Development Indicators (WDI) database; alcohol consumption from OECD Health database and divorce rates from EUROSTAT; and real gross domestic product per capita, its growth rate, and unemployment rate from the Federal Reserve Economic Database (FRED). Definitions and descriptive statistics for all these variables are included in Table 1.

[Insert Table1 around here]

\footnotetext{
${ }^{3}$ The EPU index data, as well as their detailed description, can be obtained from http://www. policyuncertainty.com/us_historical.html.
} 


\subsection{Empirical Methodology}

Our baseline equation to be estimated is as follows:

$$
\begin{aligned}
S R_{i t} & =\alpha+\beta_{1} E P U_{t}+\beta_{2} \text { Unemp }_{t}+\beta_{3} \text { Growth }_{t}+\beta_{4} G D P_{t}+\beta_{5} D i v_{t}+\beta_{6} A l c_{t} \\
& +\beta_{7} \text { Fert }_{t}+\varepsilon_{t}
\end{aligned}
$$

where $S R_{i t}$ is the natural logarithm of suicide rates per 100,000 of $i$ population, where $i=$ overall, male, female, over time $t$, where $t=1950, \ldots, 2013 . E P U_{t}$ is the natural logarithm of economic policy uncertainty index of Baker et al (2015) and measures policyrelated economic uncertainty in the United States. Unemp $p_{t}$ is the natural logarithm of unemployment rate; $G$ rowth ${ }_{t}$ denotes per capita real GDP growth; $G D P_{t}$ is the natural logarithm of real per capita GDP; Divorce $t_{t}$ is the natural logarithm of divorce rate; $A / c_{t}$ is the natural logarithm of litres of per capita alcohol consumption; Fert $t_{t}$ is the natural logarithm of fertility rate and $\varepsilon_{t}$ is the error term.

\section{Estimation results}

\subsection{Baseline Results}

The results of model (1) for the overall, male and female population across all ages, are presented in Table 2. According to these results, increased economic policy uncertainty is significantly associated with increased suicide rates in the US only for the male population across all ages, while the female population is relatively insulated to increases in economic policy uncertainty. This result is in line with Brainerd (2001) who fi that male suicide rates are highly sensitive to the state of the macroeconomy, while female suicide rates are insensitive to the state of the macroeconomy. The fact that economic policy uncertainty may lead to worsened employment position, increased fi insecurity and greater fear of job loss can be expected to produce more psychological pressure on men than on women, given that men are on average the primary household-income providers. According to the Pew Research Center analysis of data from the U.S. Census Bureau, 40 percent of all households with children under the age of 18 include mothers who are either the sole or primary source 
of income for the family. While the share has risen drastically from $11 \%$ in 1960 , the numbers suggest that men still remain the primary breadwinners in $60 \%$ of the US households. ${ }^{4} \mathrm{~A}$ similar pattern is observed for unemployment, as it coefficient is positive and statistically significant only for the male population across all ages in the US. These results again point to the direction that males are more heavily affected by the state of the macroeconomy compared to females (seee.g. Brainerd, 2001; Antonakakis and Collins, 2014, 2015). Annual economic growth is predicted to significantly increase male suicide rates. At fi this might seem contradictory, however, it is in line with the fi dings of Unnithan et al (1994); Lester (1996), who show that economic growth increases rates of suicide. Moreover, higher GDP (income) is signifi tly associated with lower suicide rates among both sexes of all ages. This result is again in line with many studies suggesting that suicide rates have a negative association with income (e.g. Chuang and Huang, 1997; Brainerd, 2001; Neumayer, 2003; Andrés, 2005; Chuang and Huang, 2007; Minoiu and Andres, 2008; Altinanahtar and Halicioglu, 2009; Andrés and Halicioglu, 2010, 2011; Okada and Samreth, 2013), but are odds with others suggesting the opposite effect (e.g. Virén, 1999; Jungeilges and Kirchgassner, 2002).

The results related to divorce rates reveal opposing effects to suicide rates across the male and female population in the US. Specifically, the results indicate that divorce rates have suicide-increasing effects for the male population, while suicide-reducing effects for the female population, and which are in line with the existing literature (see, for instance, Kposowa, 2003; Neumayer, 2003; Koo and Cox, 2008; Andrés and Halicioglu, 2011; Antonakakis and Collins, 2014; Scourfi and Evans, 2015, among others). For instance, Kposowa (2003), using data from the US National Longitudinal Mortality Study (NLMS), over the period 1979-1989, fi that divorced men are over eight times more likely to commit suicide than divorced women. This may seem plausible if marriage serves to over-regulate the lives of women. In that case, increasing divorce rates may be, among others, the result of fi independence for women, laws favouring women in fi settlements and women's search

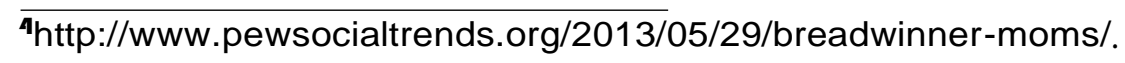


for identity and freedom. For example, Kposowa (2003) argues that, following a divorce settlement, custody of children is more likely to be given to the wife, as in many jurisdictions in the US there seems to be an implicit assumption that the bond between a woman and her children is stronger than that between a man and his children. This in turn leaves the husband with symptoms of betrayal, bitterness, anxiety, and depression, reduced selfesteem, and a sense of a "life not worth living", thus increasing the risk of committing suicide. In fact, the study of Scourfi and Evans (2015) presents an overview of the sociological explanations that may be used to understand the elevated risk factor in men following divorce and separation. According to Scourfi and Evans (2015), the explanations of the aforementioned phenomenon can be summarised under the following conceptual themes: the changing nature of intimacy, men's loss of honor, marriage as a more positive experience for men than for women, control in relationships, the increasing importance of the care of children for men, and men's social networks. In addition, fertility rates (a proxy for social inclusion) and alcohol consumption are also significant predictors of female suicides. In particular, increases in fertility rates have significant suicide-reducing effects, while increases in alcohol consumption have significant suicide increasing effects in the female population in the US.

\section{[Insert Table 2 around here]}

To what extent there are diff in the impact of economic policy uncertainty on suicides across age groups? To answer this question, we now turn, by re-estimating model (1) with disaggregated gender-specifi suicide rates data for seven age groups, namely 15-24, 25-34, 35-44, 45-54, 55-64, 65-74 and 75-84 years. These results are presented in Tables 3-5.

[Insert Table 3-5 around here]

Tables 3-5 suggest age-specific diff in theimpact of economic policy uncertaintyon suicidal behaviour. In particular, we observe that economic policy uncertainty is significantly associated with increased male suicide rates only for the younger segments (15-34) and the older segments (65-84) of the US male population, while the female population across 
all ages is found to be resilient to changes in economic policy uncertainty. The fact that only younger and older males are affected by economic policy uncertainty could be due to increased insecurity of young entrepreneurs entering the labour market and to uncertainty about pensions, respectively. ${ }^{5}$ Increased unemployment leads to significant increases in male suicide rates between the 35-64 age group and female suicide rates in the 45-64 age group (e.g. the middle aged, and those close to pension). Higher economic growth is signifi tly associated with higher male suicide rates between 25-34 and 65-84, while with lower male suicide rates between 45-54. Females seem to be resilient to variations in economic growth. Higher GDP is significantly associated with lower male suicide rates in the 25-34 and 5584 age groups, while in the female population is significantly associated with lower suicide rates among all age groups. Higher divorce rates significantly increase male suicide rates for the younger segments (15-34) and the older segments (65-84) of the US population, while reduce suicide rates of the middle-aged (35-64) males and middle-aged (25-64) females. The effects of changes in alcohol consumption on changes in suicide rates diff by gender and age group, which demonstrates once again that focusing on the total population alone can mask divergent effects that can cancel each other out when subgroups are combined. In particular, increases in alcohol consumption are associated with increased male suicides rates in the 5564 age group and increased female suicides rates in the $45-64$ age group, while reduced male suicide rates in the 35-44 age group. Finally, higher fertility leads to lower suicide rates of males in the 35-44 age group and lower suicide rates of the most fertile female population (i.e. those in the 15-54 age-groups).

\footnotetext{
$\sqrt{5}$ An interesting, yet worrisome, aspect of our results is that EPU is shown to affect the age-group of 15-24 as well. This could possibly be driven by males in the age range of of 22 to 24 years, during which point in their lives the students enter into the job market after an undergraduate degree. Also, the younger generation is relatively more informed and forward-looking before entering into the job market and a bleak forecast of the economy, due to higher EPU, could lead to the increased impact on suicide rates for this age group.
} 


\subsection{Robustness Analysis}

Given that the economic policy uncertainty variables might be correlated with the unemployment rate, economic growth and income (Jones and Olson, 2013; Colombo, 2013), which in turn could result in problems of multi-collinearity, we have re-estimated model (1) by: (i) including economic policy uncertainty uncertainty as the only explanatory variable:

$$
S R_{i t}=\alpha+\beta_{1} E P U_{t}+\varepsilon_{t}
$$

and (ii) including economic policy uncertainty uncertainty, along with the rest of the sociodemographic variables (i.e alcohol consumption, divorce rates and fertility rates), but with the rest of the economic variables excluded from the model as:

$$
S R_{i t}=\alpha+\beta_{1} E P U_{t}+\beta_{2} D i v_{t}+\beta_{3} A l c_{t}+\beta_{4} F e r t_{t}+\varepsilon_{t}
$$

The results based on models (2) and (3), which are presented in Table 6 suggest qualitatively very similar effects of economic policy uncertainty on suicide mortality compared to those obtained from model (1) and, as such, provide additional robustness to our main fi

\section{[Insert Table 6 around here]}

As another robustness check, we explored the possibility of any time-delayed effects related to the manifestation of EPU on suicide rates, by estimating the following model:

$$
\begin{aligned}
S R_{i t} & =\alpha+\beta_{1} E P U_{t}+\beta_{2} E P U_{t-1}+\beta_{3} \text { Unemp }_{t}+\beta_{4} \text { Growth }_{t}+\beta_{5} G D P_{t}+\beta_{6} \text { Div }_{t} \\
& +\beta_{7} A l c_{t}+\beta_{8} F_{\text {ert }}+\varepsilon_{t}
\end{aligned}
$$

where $E P U_{t-1}$ is the fi (one-year) lag of EPU. The results of this analysis, which are presented in Table 7, suggest no significant evidence of time-delayed effects of EPU on

\footnotetext{
${ }^{6}$ The results based on models (2) and (3) for the various age sub-groups are qualitatively very similar to those obtained from model (1), regarding the effect of EPU on suicide rates, and thus not presented, however, are available upon request from the authors.
} 
suicide rates, as the fi lag of EPU is statistically insignifi $t$ across all genders. The results related to the rest of the controlled factors of suicide mortality are in line with those reported in Table $2{ }^{7}$

\section{[Insert Table 7 aroundhere]}

Finally, we examined whether the impact of EPU on suicide rates could evolve asymmetrically. That is, we investigated whether lower EPU could be associated with decreased suicide rates as opposed to higher EPU. To achieve that, we constructed two variables, namely 'high EPU' (i.e. when actual EPU is above the sample EPU average of 112.48) and 'low EPU' (i.e. when actual EPU is below the sample EPU average of 112.48), based on the existing EPU variable. The results of this experiment are presented in Table 8. According to these results, we do not fi any significant asymmetric effects between EPU and suicide rates. Put diff tly, low levels of EPU do not have any significant suicide-reducing effects, as the coefficients of "Low EPU" are statistically insignificant. Yet, only high levels of EPU are associated with increased suicide mortality only for the male population in the United States. $^{8}$

[Insert Table 8 around here]

\section{Summary and Concluding Remarks}

While it has long been recognised that periods of economic uncertainty, characterised by increased unemployment and lower economic activity, are associated with increased suicide rates, no study has examined the impact of policy-related economic uncertainty on suicide mortality. In this study we examine whether policy-related economic uncertainty has an impact on suicide mortality in the United States over the period 1950-2013, while controlling

\footnotetext{
${ }^{7}$ The results of this analysis for the various age sub-groups point to similar conclusions. These results are available upon request from the authors.

${ }^{8}$ Once again, the results for the various age sub-groups point to similar conclusions and thus are not presented, however, are available upon request from the authors.
} 
for several other socioeconomic determinants of suicide mortality, as well as age- and genderspecificities. The results of the analysis, which remain robust to a battery of checks, reveal that increased economic policy uncertainty is associated with increased suicide mortality of the youngest and the oldest segments of the male population in the United States, while the female population across all ages is found to be resilient to policy-related economic uncertainty.

Our results have important policy implications. Economic uncertainty is unavoidable, however, what should be avoided, via clear cut transparency in the policy making of the US government, is extreme increases in uncertainty (i.e., beyond the mean). Since as our results show, it is higher uncertainty that tends to causes increases in suicide rates, but lower uncertainty does not necessarily reduce suicide rates. So, from a macroeconomic perspective, while policy making can prevent increases in suicide rates by keeping exorbitant increases in uncertainty at check, suicide rates cannot be reduced by lower macroeconomic policy uncertainty. But, an important component of the policy making should be the information conveyed to the general public, and in particular, the young and the old males, that the government is making strong efforts in ensuring lower-levels of uncertainty. This line of reasoning makes sense, as this uncertainty is newspaper-based, and hence, conveying strong policy measures to keep uncertainty at check should not be a problem. At the same time, at a micro-level, given that EPU increase causes the suicide rates in younger and older males to increase, government should aim to provide counselling services to vulnerable candidates, though identifying such cases could be a major informational problem. However, in this regard, transparency of policy making and conveying it to the economy in general, again takes center stage. The bottom line of our analysis is that uncertainty should be kept within bounds and attempts to do so must be well-publicised. Of course, at the same time, the importance of other predictors in affecting suicide rates like unemployment and growth slowdown cannot be ignored, but these variables are likely to improve with reduction in EPU.

As a potential avenue, that weleave for future research, it would be interesting to examine whether any threshold effects related to economic policy uncertainty on suicide mortality 
can be determined endogenously in the spirit of Dagenais (1969). In addition, it might also beinteresting to perform a time-varying analysis to see how the relationship between suicide rates and economic policy uncertainty has evolved over time.

\section{Acknowledgements}

We would like to thank the editor (Filomena Maggino) and three anonymous reviewers for very insightful comments and suggestions on a previous version of this paper. The usual disclaimer applies.

\section{References}

Altinanahtar A, Halicioglu F (2009) A Dynamic Econometric Model of Suicides in Turkey. Journal of Behavioral and Experimental Economics 38(6):903 - 907, DOI http://dx.doi.org/10.1016/j.socec.2009.05. 008

Andrés AR (2005) Income Inequality, Unemployment, and Suicide: A Panel Data Analysis of 15 European Countries. Applied Economics 37(4):439 - 451, DOI 10.1080/0003684042000295304

Andrés AR, Halicioglu F (2010) Determinants of Suicides in Denmark: Evidence from Time Series Data. Health Policy 98(2-3):263 - 269, DOI 10.1016/j.healthpol.2010.06.023

Andrés AR, Halicioglu F (2011) Testing the Hypothesis of the Natural Suicide Rates: Further Evidence from OECD Data. Economic Modelling 28(1):22 - 26, DOI 10.1016/j.econmod.2010.10.004

Antonakakis N, Collins A (2014) The Impact of Fiscal Austerity on Suicide: On the Empirics of a Modern Greek Tragedy. Social Science \& Medicine 112(C):39 - 50, DOI 10.1016/j.socscimed.2014.04.019

Antonakakis N, Collins A (2015) The Impact of Fiscal Austerity on Suicide Mortality: Evidence Across the Eurozone' Periphery' . Social Science \& Medicine 145:63 - 78, DOI http://dx.doi.org/10.1016/j.socscimed. 2015.09.033

Baker SR, Bloom N, Davis SJ (2015) Measuring Economic Policy Uncertainty. NBER Working Papers 21633, National Bureau of Economic Research, Inc, URL http://www.nber.org/papers/w21633.pdf

Bonamore G, Carmignani F, Colombo E (2015) Addressing the Unemployment-Mortality Conundrum: Nonlinearity is the Answer. Social Science \& Medicine 126:67 - 72, DOI http://dx.doi.org/10.1016/j.socscimed. 2014.12.017

Brainerd E (2001) Economic Reform and Mortality in the Former Soviet Union: A Study of the Suicide Epidemic in the 1990s. European Economic Review $45(4$ - 6):1007 - 1019, DOI 10.1016/S0014-2921(01) 00108-8 
Branas CC, Kastanaki AE, Michalodimitrakis M, Tzougas J, Kranioti EF, Theodorakis PN, Carr BG, Wiebe DJ (2015) The Impact of Economic Austerity and Prosperity Events on Suicide in Greece: A 30-Year Interrupted Time-Series Analysis. BMJ Open 5(1), DOI 10.1136/bmjopen-2014-005619

Chang SS, Sterne J, Huang WC, Chuang HL, Gunnell D (2010) Association of Secular Trends in Unemployment with Suicide in Taiwan, 1959-2007: A Time-Series Analysis. Public Health 124(1):49 - 54, DOI http://dx.doi.org/10.1016/j.puhe.2009.11.005

Chang SS, Stuckler D, Yip P, Gunnell D (2013) Impact of 2008 Global Economic Crisis on Suicide: Time Trend Study in 54 Countries. BMJ 347:1 - 15, DOI 10.1136/bmj.f5239

Chen J, Choi YJ, Mori K, Sawada Y, Sugano S (2012) Socio-Economic Studies On Suicide: A Survey. Journal of Economic Surveys 26(2):271 - 306, DOI 10.1111/j.1467-6419.2010.00645.x

Chuang HL, Huang WC (1997) Economic and Social Correlates of Regional Suicide Rates: A Pooled Crosssection and Time-series Analysis. Journal of Behavioral and Experimental Economics 26(3):277 - 289, DOI 10.1016/S1053-5357(97)90021-4

Chuang HL, Huang WC (2007) A Re-Examination of the Suicide Rates in Taiwan. Social Indicators Research 83(3):465 - 485, DOI 10.1007/s11205-006-9056-4

Colombo V (2013) Economic Policy Uncertainty in the US: Does it Matter for the Euro Area? Economics Letters 121(1):39 - 42, DOI 10.1016/j.econlet.2013.06.024

Dagenais MG (1969) A Threshold Regression Model. Econometrica 37(2):193 - 203

Daly MC, Wilson DJ (2006) Keeping up with the Joneses and Staying Ahead of the Smiths: Evidence from Suicide Data. Working Paper Series 2006-12, Federal Reserve Bank of San Francisco, URL http: //ideas.repec.org/p/fip/fedfwp/2006-12.html

Durkheim E (1897) Le Suicide: Étude de Sociologie. Alcan, Paris. (Spaulding, J.A., Simpson, G (Trans.), 1952. Suicide: A Study of Sociology). Free Press, New York

Ferrara L, Gurin P (2015) What Are The Macroeconomic Effects of High-Frequency Uncertainty Shocks? EconomiX Working Papers 2015 - 12, University of Paris West - Nanterre la Défense, EconomiX, URL http://EconPapers.repec.org/RePEc:drm:wpaper:2015-12

Fountoulakis KN, Savopoulos C, Apostolopoulou M, Dampali R, Zaggelidou E, Karlafti E, Fountoukidis I, Kountis P, Limenopoulos V, Plomaritis E, Theodorakis P, Hatzitolios AI (2015) Rate of Suicide and Suicide Attempts and their Relationship to Unemployment in Thessaloniki Greece (20002012). Journal of Affective Disorders 174:131 - 136, DOI http://dx.doi.org/10.1016/j.jad.2014.11.047

Garcy AM, Vger D (2012) The Length of Unemployment Predicts Mortality, Differently in Men and Women, and by Cause of Death: A Six YearMortality Follow-up of the Swedish 19921996Recession. SocialScience \& Medicine 74(12):1911 - 1920, DOI http://dx.doi.org/10.1016/j.socscimed.2012.01.034

Goldman-Mellor S (2016) Unemployment and Mental Health. In: Friedman HS (ed) Encyclopedia of Mental 
Health (Second Edition), second edition edn, Academic Press, Oxford, pp 350 - 355, DOI http://dx.doi. org/10.1016/B978-0-12-397045-9.00053-7

Gonzalez F, Quast T (2010) Mortality and Business Cycles by Level of Development: Evidence from Mexico. Social Science \& Medicine 71(12):2066 - 2073, DOI http://dx.doi.org/10.1016/j.socscimed.2010.09.047

Helliwell J (2007) Well-Being and Social Capital: Does Suicide Pose a Puzzle? Social Indicators Research 81(3):455 - 496, DOI 10.1007/s11205-006-0022-y

Hsu CY, Chang SS, Lee ES, Yip PS (2015) Geography of Suicide in Hong Kong: Spatial Patterning, and Socioeconomic Correlates and Inequalities. Social Science \& Medicine 130:190 - 203, DOI http://dx.doi. org/10.1016/j.socscimed.2015.02.019

Inoue K, Tanii H, Kaiya H, Abe S, Nishimura Y, Masaki M, Okazaki Y, Nata M, Fukunaga T (2007) The Correlation Between Unemployment and Suicide Rates in Japan between 1978 and 2004. Legal Medicine 9(3):139 - 142, DOI http://dx.doi.org/10.1016/j.legalmed.2006.11.004

Jones PM, Olson E (2013) The Time-Varying Correlation between Uncertainty, Output, and Inflation: Evidence from a DCC-GARCH Model. Economics Letters 118(1):33 - 37, DOI http://dx.doi.org/10.1016/ j.econlet.2012.09.012

Jungeilges J, Kirchgassner G (2002) Economic Welfare, Civil Liberty, and Suicide: An Empirical Investigation. The Journal of Socio-Economics 31(3):215 - 231, DOI 10.1016/S1053-5357(02)00116-6

Kang W, Lee K, Ratti RA (2014) Economic Policy Uncertainty and Firm-Level Investment. Journal of Macroeconomics 39, Part A:42 - 53, DOI http://dx.doi.org/10.1016/j.jmacro.2013.10.006

Koo J, Cox WM (2008) An Economic Interpretation of Suicide Cycles in Japan. Contemporary Economic Policy 26(1):162 - 174, DOI 10.1111/j.1465-7287.2007.00042.x

Kposowa AJ (2003) Divorce and Suicide Risk. Journal of Epidemiology and Community Health 57(12):993 Kuroki M (2010) Suicide and unemployment in Japan: Evidence from municipal level suicide rates and agespecific suicide rates. The Journal of Socio-Economics 39(6):683 - 691, DOI http://dx.doi.org/10.1016/j. socec.2010.06.009

Lester D (1996) Patterns of Suicide and Homicide in the World). Nova Science Publishers, New York

Lundin A, Lundberg I, Allebeck P, Hemmingsson T (2012) Unemployment and Suicide in the Stockholm Population: A Register-Based Study on 771,068 Men and Women. Public Health 126(5):371 - 377, DOI http://dx.doi.org/10.1016/j.puhe.2012.01.020

Miller DL, Page ME, Stevens AH, Filipski M (2009) Why Are Recessions Good for Your Health? American Economic Review 99(2):122 - 127, DOI 10.1257/aer.99.2.122

Minoiu C, Andres AR (2008) The Effect of Public Spending on Suicide: Evidence from U.S. State Data. The Journal of Socio-Economics 37(1):237 - 261, DOI 10.1016/j.socec.2006.09.001

Morrell S, TaylorR, Quine S, KerrC (1993) Suicide and unemployment in Australia 19071990. SocialScience 
\& Medicine 36(6):749 - 756, DOI http://dx.doi.org/10.1016/0277-9536(93)90035-3

Morselli H (1882) Suicide: An Essay on Comparative Moral Statistics (originally published 1881). D. Appleton and Company, New York

Neumayer E (2003) Are Socioeconomic Factors Valid Determinants of Suicide? Controlling for National Cultures of Suicide with Fixed Effects Estimation. Cross-Cultural Research 37:307 - 329, DOI 10.1177/ 1069397103253708

Noh YH (2009) Does Unemployment Increase Suicide Rates? The OECD Panel Evidence. Journal of Economic Psychology 30(4):575 - 582, DOI http://dx.doi.org/10.1016/j.joep.2009.04.003

Dos Santos M (2015) Unemployment, Mental Health Worker and Suicide: A Systematic Review. European Psychiatry 30, Supplement 1:375, DOI http://dx.doi.org/10.1016/S0924-9338(15)30295-9, abstracts of the 23rd European Congress of Psychiatry

Nordt C, Warnke I, Seifritz E, Kawohl W (2015) Modelling suicide and unemployment: a longitudinal analysis covering 63 countries, 200011. The Lancet Psychiatry 2(3):239 - 245, DOI http://dx.doi.org/10. 1016/S2215-0366(14)00118-7

Okada K, Samreth S (2013) A study on the Socio-economic Determinants of Suicide: Evidence from 13 European OECD Countries. Journal of Behavioral and Experimental Economics45(C)

Pástor L, Veronasi P (2012) Uncertainty about Government Policy and Stock Prices. The Journal of Finance 67(4):1219 - 1264, DOI 10.1111/j.1540-6261.2012.01746.x

Pellegrini LC, Rodriguez-Monguio R (2013) Unemployment, Medicaid Provisions, the Mental Health Industry, and Suicide. The Social Science Journal 50(4):482 - 490, DOI http://dx.doi.org/10.1016/j.soscij.2013. 09.013

Platt S, Micciolo R, Tansella M (1992) Suicide and unemployment in Italy: Description, analysis and interpretation of recent trends. Social Science \& Medicine 34(11):1191 - 1201, DOI http://dx.doi.org/10. 1016/0277-9536(92)90312-E

Ruhm CJ (2000) Are Recessions Good for Your Health? The Quarterly Journal of Economics 115(2):617 650, DOI 10.1162/003355300554872

Scourfield J, Evans R (2015) Why Might Men Be More at Risk of Suicide After a Relationship Breakdown? Sociological Insights. American Journal of Men's Health 9(5):380 - 384, DOI 10.1177/1557988314546395

Stuckler D, Basu S, Suhrcke M, Coutts A, McKee M (2011) Effects of the 2008 Recession On Health: a First Look at European Data. The Lancet 378(9786):124 - 125, DOI 10.1016/S0140-6736(11)61079-9

Suhrcke M, Stuckler D (2012) Will the Recession be Bad for our Health? It Depends. Social Science \& Medicine 74(5):647 - 653, DOI 10.1016/j.socscimed.2011.12.011

Swinscow D (1951) Some Suicide Statistics. British Medical Journal 1(4720):1417 - 1423

Unnithan NP, Huff-Corzine L, Corzine J, Whitt HP (1994) The Currents of Lethal Violence: An Integrated 
Model of Suicide and Homicide). State University of New York Press, Albany

Virén M (1999) Testing the "Natural Rate of Suicide" Hypothesis. International Journal of Social Economics 26(12):1428 - 1440, DOI http://dx.doi.org/10.1108/03068299910370535

Wang Y, Chen CR, Huang YS (2014) Economic Policy Uncertainty and Corporate Investment: Evidence from China. Pacific-Basin Finance Journal 26:227 - 243, DOI http://dx.doi.org/10.1016/j.pacfin.2013.12. 008

Wasserman IM (1984) The Influence of Economic Business Cycles on United States Suicide Rates. Suicide and Life-Threatening Behavior 14(3):143 - 156, DOI 10.1111/j.1943-278X.1984.tb00445.x

Webb RT, Kapur N (2015) Suicide, Unemployment, and the Effect of Economic Recession. The Lancet Psychiatry 2(3):196 - 197, DOI http://dx.doi.org/10.1016/S2215-0366(14)00129-1 
Figure 1: Suicide rates per 100,000 residents (\%) and Economic policy uncertainty in the United States, $1950-2013$

\section{EPU and male suicide rates}

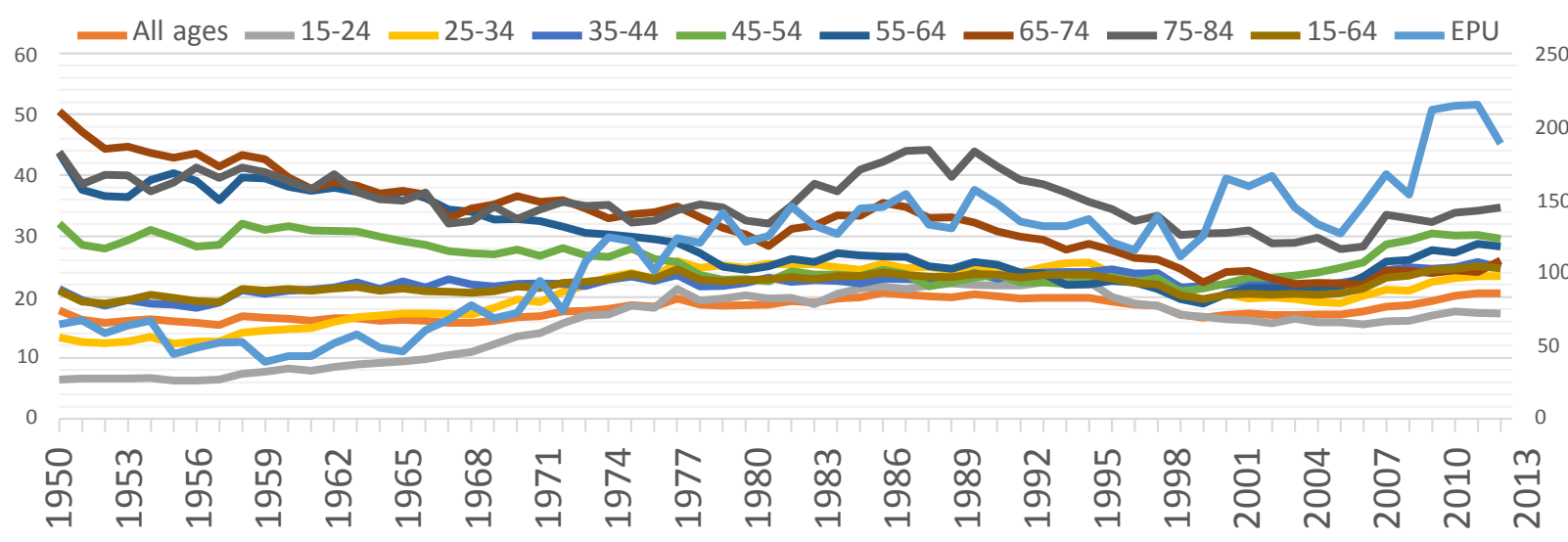

EPU and female suicide rates

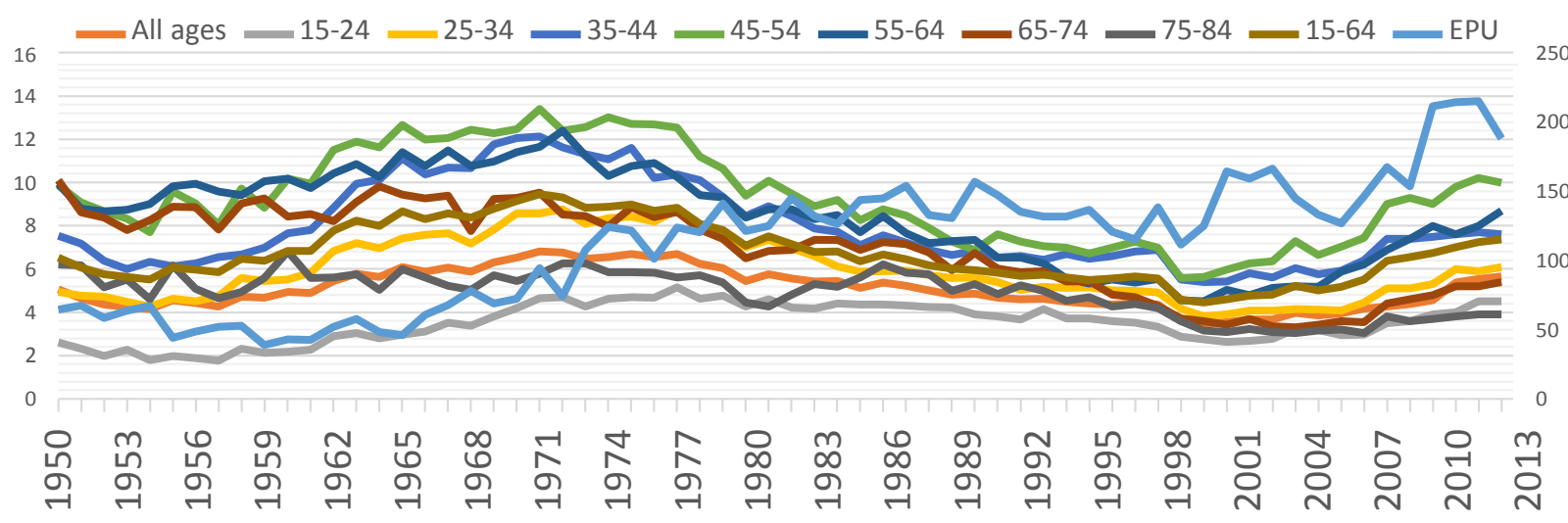

EPU and overall suicide rates

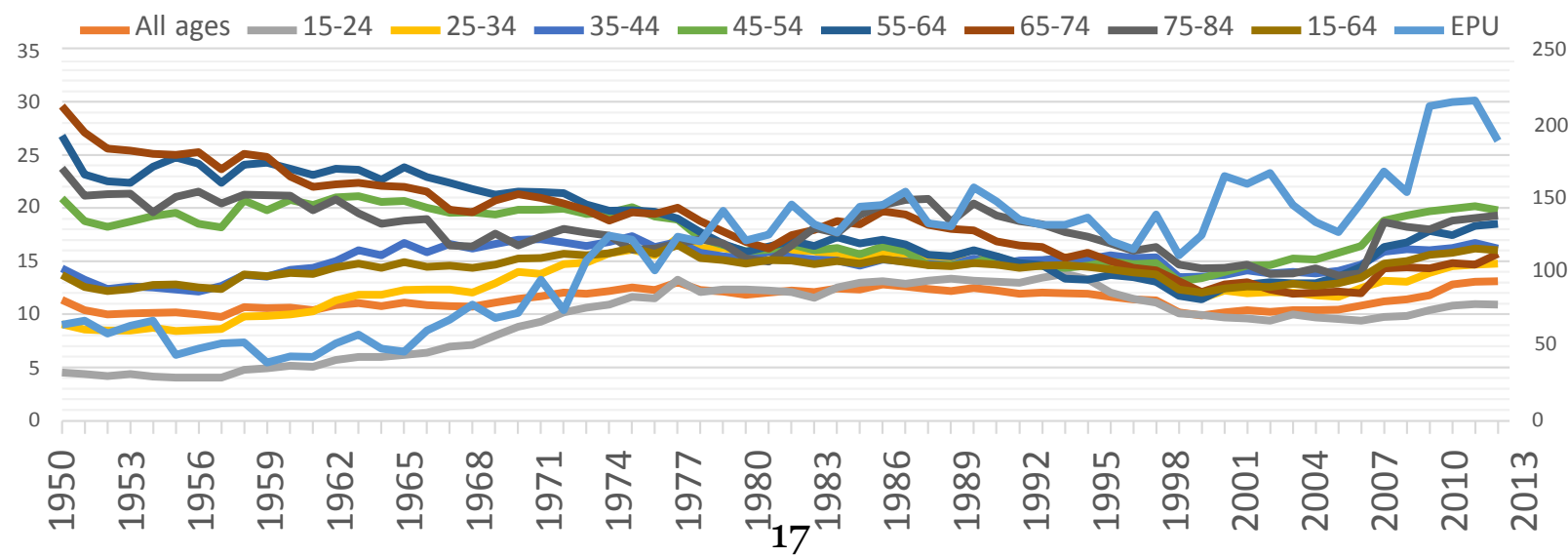

Note: Suicide rates (left axis); EPU (right axis).

Source: WHO, CDC and Baker et al (2015). 
Table 1: Variable definitions and descriptive statistics

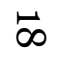

\begin{tabular}{|c|c|c|c|c|c|c|c|c|c|}
\hline Variable & & Definition & Expected Signs & Availability & Obs. & Mean & Std. & Min. & Max. \\
\hline Suicide rate & $\begin{array}{l}\text { Overall } \\
\text { All ages* } \\
15-64 \\
15-24 \\
25-34 \\
35-44 \\
45-54 \\
55-64 \\
65-74 \\
75-84\end{array}$ & $\begin{array}{l}\text { Overall suicide rates (deaths per 100,000 people) } \\
-/ / /- \\
-/ /- \\
-/ /- \\
-/ /- \\
-/ /- \\
-/ /- \\
-/ /- \\
-/ /- \\
-/ /-\end{array}$ & & $\begin{array}{l}1950-2013 \\
1950-2013 \\
1950-2013 \\
1950-2013 \\
1950-2013 \\
1950-2013 \\
1950-2013 \\
1950-2013 \\
1950-2013\end{array}$ & $\begin{array}{l}64 \\
64 \\
64 \\
64 \\
64 \\
64 \\
64 \\
64 \\
64\end{array}$ & $\begin{array}{l}11.39583 \\
14.2983 \\
9.490627 \\
13.16315 \\
15.04194 \\
17.61268 \\
18.39565 \\
18.62576 \\
18.02337\end{array}$ & $\begin{array}{l}0.9394409 \\
1.168958 \\
3.15893 \\
2.481288 \\
1.323373 \\
2.413739 \\
4.120159 \\
4.324647 \\
2.383854\end{array}$ & $\begin{array}{l}9.760564 \\
12.0323 \\
4.035516 \\
8.409575 \\
12.12502 \\
13.09132 \\
11.40695 \\
11.92625 \\
13.64309\end{array}$ & $\begin{array}{l}13.13046 \\
16.5395 \\
13.78854 \\
17.21876 \\
17.35501 \\
21.11691 \\
26.81476 \\
29.58034 \\
23.71771\end{array}$ \\
\hline & $\begin{array}{l}\text { Male } \\
\text { All ages* } \\
15-64 \\
15-24 \\
25-34 \\
35-44 \\
45-54 \\
55-64 \\
65-74 \\
75-84\end{array}$ & $\begin{array}{l}\text { Male suicide rates (deaths per } 100,000 \text { people) } \\
-/ / /- \\
-/ /- \\
-/ /- \\
-/ /- \\
-/ /- \\
-/ /- \\
-/ /- \\
-/ /- \\
-/ /-\end{array}$ & & $\begin{array}{l}1950-2013 \\
1950-2013 \\
1950-2013 \\
1950-2013 \\
1950-2013 \\
1950-2013 \\
1950-2013 \\
1950-2013 \\
1950-2013\end{array}$ & $\begin{array}{l}64 \\
64 \\
64 \\
64 \\
64 \\
64 \\
64 \\
64 \\
64\end{array}$ & $\begin{array}{l}17.96482 \\
22.03055 \\
15.36228 \\
20.44419 \\
22.32312 \\
26.24679 \\
29.19588 \\
32.69787 \\
35.86978\end{array}$ & $\begin{array}{l}1.606388 \\
1.593001 \\
5.450115 \\
4.37183 \\
1.621569 \\
3.286976 \\
6.457036 \\
7.08174 \\
4.193791\end{array}$ & $\begin{array}{l}15.41786 \\
18.89641 \\
6.255489 \\
12.36734 \\
18.21075 \\
20.93823 \\
18.88306 \\
21.94847 \\
27.90842\end{array}$ & $\begin{array}{c}20.70598 \\
25.08 \\
23.44746 \\
25.86536 \\
25.7 \\
32.05233 \\
43.62822 \\
50.47467 \\
44.14298\end{array}$ \\
\hline & $\begin{array}{l}\text { Female } \\
\text { All ages* } \\
15-64 \\
15-24 \\
25-34 \\
35-44 \\
45-54 \\
55-64 \\
65-74 \\
75-84\end{array}$ & $\begin{array}{l}\text { Female suicide rates (deaths per } 100,000 \text { people) } \\
-/ / /- \\
-/ /- \\
-/ /- \\
-/ /- \\
-/ /- \\
-/ /- \\
-/ /- \\
-/ /- \\
-/ /-\end{array}$ & & $\begin{array}{l}1950-2013 \\
1950-2013 \\
1950-2013 \\
1950-2013 \\
1950-2013 \\
1950-2013 \\
1950-2013 \\
1950-2013 \\
1950-2013\end{array}$ & $\begin{array}{l}64 \\
64 \\
64 \\
64 \\
64 \\
64 \\
64 \\
64 \\
64\end{array}$ & $\begin{array}{l}5.082131 \\
6.754747 \\
3.50256 \\
5.952274 \\
7.947333 \\
9.313271 \\
8.384417 \\
6.882939 \\
4.917183\end{array}$ & $\begin{array}{c}0.9227098 \\
1.362217 \\
0.9110156 \\
1.443787 \\
1.955453 \\
2.181941 \\
2.153352 \\
2.041012 \\
1.004528\end{array}$ & $\begin{array}{c}3.474126 \\
4.450997 \\
1.765607 \\
3.811435 \\
5.39207 \\
5.589165 \\
4.513304 \\
3.308142 \\
3.0378\end{array}$ & $\begin{array}{l}6.822641 \\
9.456391 \\
5.158654 \\
8.774343 \\
12.13671 \\
13.41113 \\
12.38218 \\
10.10148 \\
6.81778\end{array}$ \\
\hline
\end{tabular}

Note: * The 'all ages' suicide rate groups include also the ages below 15 and above 84 . 
Table 2: Economic policy uncertainty and suicide rates (per 100,000 resident), by sex in the United States, $1950-2013$

\begin{tabular}{llll}
\hline \multirow{3}{*}{ Gender } & $(1)$ & $(2)$ & $(3)$ \\
Age & Overall & Male & Female \\
\hline EPU & All & All & All \\
& $0.1574^{* *}$ & $0.185^{* * *}$ & 0.0710 \\
Unemployment & $(0.0679)$ & $(0.0639)$ & $(0.1216)$ \\
& $\left(0.0905^{* * *}\right.$ & $0.0965^{* * *}$ & 0.0885 \\
Growth & $0.0050^{*}$ & $(0.0353)$ & $(0.0751)$ \\
& $(0.0027)$ & $(0.0026)$ & $(0.0062)$ \\
GDP & $-0.1581^{* * *}$ & $-0.0940^{* *}$ & $-0.3906^{* * *}$ \\
& $(0.0397)$ & $(0.0364)$ & $(0.0865)$ \\
Divorce & 0.0255 & $0.1974^{* *}$ & $-0.4648^{* *}$ \\
& $(0.0876)$ & $(0.0742)$ & $(0.2082)$ \\
Alcohol & -0.0863 & -0.2710 & $0.5834^{*}$ \\
& $(0.1925)$ & $(0.1839)$ & $(0.3461)$ \\
Fertily & -0.1139 & 0.1085 & $-0.7788^{* *}$ \\
& $(0.1634)$ & $(0.1720)$ & $(0.2930)$ \\
Constant & $3.1804^{* * *}$ & $2.9193^{* * *}$ & $4.5603^{* * *}$ \\
& $(0.8117)$ & $(0.8219)$ & $(1.4902)$ \\
\hline Observations & 53 & 53 & 53 \\
$R^{2}$ & 0.694 & 0.785 & 0.846 \\
$R^{2}$ adjusted & 0.647 & 0.752 & 0.822 \\
F-statistic & 15.84 & 38.50 & 23.78 \\
\hline
\end{tabular}

Note: Heteroscedasticity and autocorrelation (HAC) adjusted standard errors in parentheses. $* * * \mathrm{p}<0.01$, $* * \mathrm{p}<0.05, * \mathrm{p}<0.1$ 
Table 3: Economic policy uncertainty and overall suicide rates (per 100,000 resident), by sex and age-group in the United States, 1950 - 2013

\begin{tabular}{llllllll}
\hline \multirow{2}{*}{ Age } & $(1)$ & $(2)$ & $(3)$ & $(4)$ & $(5)$ & $(6)$ & $(7)$ \\
& $15-24$ & $25-34$ & $35-44$ & $45-54$ & $55-64$ & $65-74$ & $75-84$ \\
\hline EPU & $0.2510 * *$ & $0.1451^{* *}$ & -0.0044 & -0.0375 & 0.0856 & $0.1954 *$ & $0.3689 * *$ \\
Unemployment & $(0.1031)$ & $(0.0711)$ & $(0.0660)$ & $(0.0944)$ & $(0.1079)$ & $(0.1087)$ & $(0.1586)$ \\
& -0.0357 & 0.0489 & 0.0386 & $0.2043 * * *$ & $0.1874 * * *$ & 0.0716 & $0.1253 *$ \\
Growth & $(0.0703)$ & $(0.0452)$ & $(0.0390)$ & $(0.0638)$ & $(0.0663)$ & $(0.0590)$ & $(0.0736)$ \\
& 0.0069 & 0.0027 & $-0.0066 *$ & -0.0084 & -0.0001 & 0.0088 & 0.0137 \\
GDP & $(0.0046)$ & $(0.0037)$ & $(0.0038)$ & $(0.0052)$ & $(0.0050)$ & $(0.0063)$ & $(0.0084)$ \\
& -0.1399 & $-0.2367 * * *$ & $-0.1322^{* *}$ & -0.1177 & $-0.2949 * * *$ & $-0.4751 * * *$ & $-0.2707 * *$ \\
Divorce & $(0.0839)$ & $(0.0567)$ & $(0.0555)$ & $(0.0959)$ & $(0.0867)$ & $(0.0798)$ & $(0.1014)$ \\
& $0.7452 * * *$ & $0.1754 * *$ & $-0.3077 * * *$ & $-0.7670 * * *$ & $-0.6776 * * *$ & 0.0018 & 0.1229 \\
Alcohol & $(0.1609)$ & $(0.0828)$ & $(0.0972)$ & $(0.2032)$ & $(0.1881)$ & $(0.1289)$ & $(0.1588)$ \\
& -0.5002 & -0.2313 & -0.0930 & 0.4049 & $0.7441 * * *$ & 0.0824 & -0.2647 \\
Fertily & $(0.4148)$ & $(0.2796)$ & $(0.2287)$ & $(0.2721)$ & $(0.2715)$ & $(0.3101)$ & $(0.3547)$ \\
& -0.2711 & $-0.4393 * *$ & $-0.5960 * * *$ & $-0.6104 *$ & -0.2257 & 0.1562 & 0.5913 \\
Constant & $(0.3148)$ & $(0.1951)$ & $(0.1690)$ & $(0.3136)$ & $(0.2871)$ & $(0.2664)$ & $(0.3664)$ \\
& 2.7082 & $4.5636 * * *$ & $4.9600 * * *$ & $4.3452 * * *$ & $4.1901 * * *$ & $5.7062 * * *$ & $3.2316 *$ \\
& $(1.7132)$ & $(1.1458)$ & $(0.9568)$ & $(1.5775)$ & $(1.3790)$ & $(1.3537)$ & $(1.6685)$ \\
\hline Observations & 53 & 53 & 53 & 53 & 53 & 53 & 53 \\
$R^{2}$ & 0.937 & 0.862 & 0.541 & 0.806 & 0.897 & 0.892 & 0.467 \\
R $^{2}$ adjusted & 0.928 & 0.841 & 0.470 & 0.776 & 0.881 & 0.876 & 0.384 \\
F-statistic & 104.4 & 37.04 & 6.703 & 49.00 & 76.81 & 43.21 & 8.268 \\
\hline
\end{tabular}

Note: Heteroscedasticity and autocorrelation (HAC) adjusted standard errors in parentheses. $* * * \mathrm{p}<0.01$, $* * \mathrm{p}<0.05, * \mathrm{p}<0.1$ 
Table 4: Economic policy uncertainty and male suicide rates (per 100,000 resident), by sex and age-group in the United States, $1950-2013$

\begin{tabular}{llllllll}
\hline \multirow{2}{*}{ Age } & $(1)$ & $(2)$ & $(3)$ & $(4)$ & $(5)$ & $(6)$ & $(7)$ \\
\hline EPU & $15-24$ & $25-34$ & $35-44$ & $45-54$ & $55-64$ & $65-74$ & $75-84$ \\
\hline \multirow{2}{*}{ Unemployment } & $0.2687 * *$ & $0.1838 * *$ & 0.0523 & -0.0238 & 0.1133 & $0.1922^{*}$ & $0.4022^{* * *}$ \\
& $(0.1086)$ & $(0.0696)$ & $(0.0464)$ & $(0.0812)$ & $(0.0921)$ & $(0.0966)$ & $(0.1490)$ \\
Growth & $(0.0466$ & 0.0540 & $0.0577 * *$ & $0.2052^{* * *}$ & $0.1630 * * *$ & 0.0094 & 0.0342 \\
& 0.0067 & $0.0052^{*}$ & -0.0031 & $-0.0074 *$ & 0.0016 & $0.0105 *$ & $0.0174 * *$ \\
GDP & $(0.0048)$ & $(0.0030)$ & $(0.0023)$ & $(0.0039)$ & $(0.0043)$ & $(0.0053)$ & $(0.0074)$ \\
& -0.1170 & $-0.1727 * * *$ & -0.0506 & -0.0358 & $-0.2873 * * *$ & $-0.4572 * * *$ & $-0.2761 * * *$ \\
Divorce & $(0.0910)$ & $(0.0567)$ & $(0.0363)$ & $(0.0807)$ & $(0.0742)$ & $(0.0615)$ & $(0.0801)$ \\
& $0.8920 * * *$ & $0.3774 * * *$ & $-0.1055^{* *}$ & $-0.6245 * * *$ & $-0.5772 * * *$ & $0.1780 *$ & $0.4320 * * *$ \\
Alcohol & $(0.1880)$ & $(0.0830)$ & $(0.0511)$ & $(0.1700)$ & $(0.1569)$ & $(0.1051)$ & $(0.1492)$ \\
& -0.6719 & -0.4679 & $-0.3770 * *$ & 0.1853 & $0.4551 *$ & -0.0619 & -0.1866 \\
Fertily & $(0.4202)$ & $(0.2801)$ & $(0.1641)$ & $(0.2326)$ & $(0.2456)$ & $(0.2583)$ & $(0.3151)$ \\
& -0.1857 & -0.2769 & $-0.2834 * *$ & -0.3422 & -0.1055 & 0.2623 & 0.2773 \\
Constant & $(0.3507)$ & $(0.2135)$ & $(0.1280)$ & $(0.2764)$ & $(0.2487)$ & $(0.2395)$ & $(0.3594)$ \\
& 3.0318 & $4.3561 * * *$ & $4.4235 * * *$ & $4.0239 * * *$ & $4.8979 * * *$ & $6.2355^{* * *}$ & $3.1677 * *$ \\
& $(1.8258)$ & $(1.1946)$ & $(0.7133)$ & $(1.3704)$ & $(1.2043)$ & $(1.1514)$ & $(1.4977)$ \\
\hline Observations & 53 & 53 & 53 & 53 & 53 & 53 & 53 \\
$\mathrm{R}^{2}$ & 0.944 & 0.905 & 0.561 & 0.800 & 0.906 & 0.904 & 0.544 \\
$\mathrm{R}^{2}$ adjusted & 0.936 & 0.890 & 0.493 & 0.769 & 0.891 & 0.889 & 0.473 \\
F-statistic & 139.9 & 56.30 & 7.317 & 81.59 & 78.53 & 59.72 & 7.142 \\
\hline
\end{tabular}

Note: Heteroscedasticity and autocorrelation (HAC) adjusted standard errors in parentheses. $* * * \mathrm{p}<0.01$, $* * \mathrm{p}<0.05, * \mathrm{p}<0.1$ 
Table 5: Economic policy uncertainty and female suicide rates (per 100,000 resident), by sex and age-group in the United States, 1950 - 2013

\begin{tabular}{|c|c|c|c|c|c|c|c|}
\hline Age & $\begin{array}{l}(1) \\
15-24\end{array}$ & $\begin{array}{l}(2) \\
25-34\end{array}$ & $\begin{array}{l}(3) \\
35-44\end{array}$ & $\begin{array}{l}(4) \\
45-54\end{array}$ & $\begin{array}{l}(5) \\
55-64\end{array}$ & $\begin{array}{l}(6) \\
65-74\end{array}$ & $\begin{array}{l}(7) \\
75-84\end{array}$ \\
\hline \multirow[t]{2}{*}{ EPU } & 0.1693 & 0.0268 & -0.1234 & -0.0715 & 0.0224 & 0.2226 & 0.2578 \\
\hline & $(0.1434)$ & $(0.1430)$ & $(0.1469)$ & $(0.1413)$ & $(0.1532)$ & $(0.1719)$ & $(0.1595)$ \\
\hline \multirow[t]{2}{*}{ Unemployment } & 0.0886 & 0.0827 & 0.0241 & $0.1976^{*}$ & $0.2074 * *$ & 0.1362 & 0.0388 \\
\hline & $(0.0939)$ & $(0.0848)$ & $(0.0925)$ & $(0.0982)$ & $(0.0918)$ & $(0.1028)$ & $(0.0880)$ \\
\hline \multirow[t]{2}{*}{ Growth } & 0.0058 & -0.0062 & -0.0138 & -0.0094 & -0.0024 & 0.0087 & 0.0133 \\
\hline & $(0.0077)$ & $(0.0087)$ & $(0.0092)$ & $(0.0087)$ & $(0.0072)$ & $(0.0093)$ & $(0.0086)$ \\
\hline \multirow[t]{2}{*}{ GDP } & $-0.2576 * * *$ & $-0.5161 * * *$ & $-0.3956 * * *$ & $-0.3618 * * *$ & $-0.3778 * * *$ & $-0.7927 * * *$ & $-0.6844 * * *$ \\
\hline & $(0.0925)$ & (0.1102) & $(0.1305)$ & (0.1328) & $(0.1122)$ & $(0.1281)$ & (0.0961) \\
\hline \multirow[t]{2}{*}{ Divorce } & -0.0887 & $-0.5398 * *$ & $-0.8307 * * *$ & $-1.0878 * * *$ & $-0.8132 * * *$ & -0.1755 & 0.2105 \\
\hline & $(0.1653)$ & (0.2369) & $(0.2639)$ & $(0.2808)$ & $(0.2494)$ & $(0.2374)$ & $(0.1783)$ \\
\hline \multirow[t]{2}{*}{ Alcohol } & 0.5896 & 0.5767 & 0.7115 & $1.0084 * *$ & $1.6945 * * *$ & 0.4387 & -0.5687 \\
\hline & $(0.4939)$ & $(0.4246)$ & $(0.4816)$ & $(0.4162)$ & (0.3519) & $(0.5400)$ & $(0.4370)$ \\
\hline \multirow[t]{2}{*}{ Fertily } & $-0.7406 * *$ & $-1.0808 * * *$ & $-1.3607 * * *$ & $-1.2823 * * *$ & -0.4830 & -0.2257 & -0.1569 \\
\hline & $(0.3061)$ & $(0.3579)$ & $(0.4108)$ & $(0.4250)$ & $(0.3796)$ & $(0.4264)$ & $(0.3818)$ \\
\hline \multirow[t]{2}{*}{ Constant } & 2.0108 & $6.4322 * * *$ & $6.7879 * * *$ & $5.6877 * *$ & 2.7195 & $7.0434 * * *$ & $7.4285^{* * *}$ \\
\hline & $(1.8142)$ & $(1.8871)$ & $(2.1882)$ & $(2.1753)$ & (1.7836) & (2.1988) & (1.8308) \\
\hline Observations & 53 & 53 & 53 & 53 & 53 & 53 & 53 \\
\hline $\mathrm{R}^{2}$ & 0.791 & 0.863 & 0.833 & 0.856 & 0.899 & 0.897 & 0.807 \\
\hline $\mathrm{R}^{2}$ adjusted & 0.759 & 0.842 & 0.807 & 0.834 & 0.883 & 0.881 & 0.776 \\
\hline F-statistic & 29.94 & 26.24 & 18.77 & 24.51 & 61.95 & 35.14 & 25.25 \\
\hline
\end{tabular}

Note: Heteroscedasticity and autocorrelation (HAC) adjusted standard errors in parentheses. $* * * \mathrm{p}<0.01$, $* * \mathrm{p}<0.05, * \mathrm{p}<0.1$ 
Table 6: Potential multi-collinearity. Economic policy uncertainty and suicide rates (per 100,000 resident), by sex in the United States, 1950 - 2013

\begin{tabular}{|c|c|c|c|c|c|c|}
\hline & (1) & (2) & (3) & (4) & (5) & (6) \\
\hline Gender & Overall & Overall & Male & Male & Female & Female \\
\hline Age & All & All & All & All & All & All \\
\hline EPU & $\begin{array}{l}0.0999^{* * * *} \\
(0.0243)\end{array}$ & $\begin{array}{l}0.0946^{* * * *} \\
(0.0228)\end{array}$ & $\begin{array}{l}0.1484^{* * * *} \\
(0.0201)\end{array}$ & $\begin{array}{l}0.1264^{* *} \\
(0.0501)\end{array}$ & $\begin{array}{l}0.0609 \\
(0.0636)\end{array}$ & $\begin{array}{l}0.1915 \\
(0.1535)\end{array}$ \\
\hline Divorce & & $\begin{array}{l}0.1326 \\
(0.1007)\end{array}$ & & $\begin{array}{l}0.2770^{* * *} \\
(0.0794)\end{array}$ & & $\begin{array}{l}-0.2506^{* * *} \\
(0.1248)\end{array}$ \\
\hline Alcohol & & $\begin{array}{l}-0.4613 \\
\text { (o.3990) }\end{array}$ & & $\begin{array}{l}-0.0802 \\
(0.1800)\end{array}$ & & $\begin{array}{l}0.5532^{*} \\
(0.3342)\end{array}$ \\
\hline Fertility & & $\begin{array}{l}-0.1735 \\
(0.1308)\end{array}$ & & $\begin{array}{l}0.1449 \\
(0.1215)\end{array}$ & & $\begin{array}{l}-0.6211^{* * *} \\
(0.2525)\end{array}$ \\
\hline Constant & $\begin{array}{l}1.9680^{* * * *} \\
(0.1050)\end{array}$ & $\begin{array}{l}0.8617 \\
(0.6676)\end{array}$ & $\begin{array}{l}2.1983^{* * *} \\
(0.0869)\end{array}$ & $\begin{array}{l}1.5270^{* * *} \\
(0.6053)\end{array}$ & $\begin{array}{l}1.8912^{* * *} \\
(0.2916)\end{array}$ & $\begin{array}{l}4.1110^{* * * *} \\
(1.1359)\end{array}$ \\
\hline Observations & 64 & 53 & 64 & 53 & 64 & 53 \\
\hline $\mathrm{R}^{2}$ & 0.320 & 0.488 & 0.608 & 0.667 & 0.0245 & 0.743 \\
\hline $\mathrm{R}^{2}$ adjusted & 0.309 & 0.446 & 0.601 & 0.639 & 0.00879 & 0.721 \\
\hline F-statistic & 16.83 & 18.02 & 54.53 & 31.96 & 0.917 & 16.40 \\
\hline
\end{tabular}

Note: Heteroscedasticity and autocorrelation (HAC) adjusted standard errors in parentheses. $* * * \mathrm{p}<0.01$, $* * \mathrm{p}<0.05, * \mathrm{p}<0.1$ 
Table 7: Time-delayed effects of economic policy uncertainty on suicide rates (per 100,000 resident), by sex in the United States, $1950-2013$

\begin{tabular}{|c|c|c|c|}
\hline & (1) & (2) & (3) \\
\hline Gender & Overall & Male & Female \\
\hline Age & All & All & All \\
\hline EPU & $\begin{array}{l}0.1484^{* *} \\
(0.0619)\end{array}$ & $\begin{array}{l}0.1734^{* * *} \\
(0.0567)\end{array}$ & $\begin{array}{l}0.0718 \\
(0.1164)\end{array}$ \\
\hline 1st Lag of EPU & $\begin{array}{l}0.0713 \\
(0.0612)\end{array}$ & $\begin{array}{l}0.0936 \\
(0.0597)\end{array}$ & $\begin{array}{l}-0.0062 \\
(0.1004)\end{array}$ \\
\hline Unemployment & $\begin{array}{l}0.0719^{*} \\
(0.0391)\end{array}$ & $\begin{array}{l}0.0722^{* *} \\
(0.0350)\end{array}$ & $\begin{array}{l}0.0901 \\
(0.0714)\end{array}$ \\
\hline Growth & $\begin{array}{l}0.0052^{*} \\
(0.0028)\end{array}$ & $\begin{array}{l}0.0069^{* * *} \\
(0.0028)\end{array}$ & $\begin{array}{l}0.0010 \\
(0.0064)\end{array}$ \\
\hline GDP & $\begin{array}{l}-0.1933^{* * *} \\
(0.0550)\end{array}$ & $\begin{array}{l}-0.1402^{* * *} \\
(0.0510)\end{array}$ & $\begin{array}{l}-0.3875^{* * *} \\
(0.1119)\end{array}$ \\
\hline Divorce & $\begin{array}{l}0.0126 \\
(0.0888)\end{array}$ & $\begin{array}{l}0.1805^{* * *} \\
(0.0649)\end{array}$ & $\begin{array}{l}-0.4637^{* *} \\
(0.2220)\end{array}$ \\
\hline Alcohol & $\begin{array}{l}-0.1071 \\
(0.1958)\end{array}$ & $\begin{array}{l}-0.2983 \\
(0.1869)\end{array}$ & $\begin{array}{l}0.5852 \\
(0.3553)\end{array}$ \\
\hline Fertility & $\begin{array}{l}-0.0811 \\
(0.1650)\end{array}$ & $\begin{array}{l}0.1515 \\
(0.1706)\end{array}$ & $\begin{array}{l}-0.7817^{* * * *} \\
(0.2851)\end{array}$ \\
\hline Constant & $\begin{array}{l}3.2737^{* * *} \\
(0.8278)\end{array}$ & $\begin{array}{l}3.0418^{* * *} \\
(0.8189)\end{array}$ & $\begin{array}{l}4.5522 * * * \\
(1.5266)\end{array}$ \\
\hline Observations & 53 & 53 & 53 \\
\hline $\mathrm{R}^{2}$ & 0.704 & 0.799 & 0.846 \\
\hline $\mathrm{R}^{2}$ adjusted & 0.651 & 0.763 & 0.818 \\
\hline F-statistic & 14.86 & 58.03 & 22.02 \\
\hline
\end{tabular}

Note: Heteroscedasticity and autocorrelation (HAC) adjusted standard errors in parentheses. $* * * \mathrm{p}<0.01$, $* * \mathrm{p}<0.05, * \mathrm{p}<0.1$ 
Table 8: Asymmetric effects of economic policy uncertainty on suicide rates (per 100,000 resident), by sex in the United States, $1950-2013$

\begin{tabular}{|c|c|c|c|c|c|c|}
\hline & (1) & (2) & (3) & (4) & (5) & (6) \\
\hline Gender & Overall & Overall & Male & Male & Female & Female \\
\hline Age & All & All & All & All & All & All \\
\hline High EPU & $\begin{array}{l}0.2210^{* *} \\
(0.1044)\end{array}$ & & $\begin{array}{l}0.2073^{* *} \\
(0.0952)\end{array}$ & & $\begin{array}{l}0.2332 \\
(0.1531)\end{array}$ & \\
\hline Low EPU & & $\begin{array}{l}0.0147 \\
(0.0571)\end{array}$ & & $\begin{array}{l}0.0244 \\
(0.0343)\end{array}$ & & $\begin{array}{l}-0.0061 \\
(0.1404)\end{array}$ \\
\hline Unemployment & $\begin{array}{l}0.1043 \\
(0.0694)\end{array}$ & $\begin{array}{l}0.0278 \\
(0.0261)\end{array}$ & $\begin{array}{l}0.1203^{*} \\
(0.0644)\end{array}$ & $\begin{array}{l}0.0525 \\
(0.0349)\end{array}$ & $\begin{array}{l}0.0788 \\
(0.1127)\end{array}$ & $\begin{array}{l}-0.0414 \\
(0.0664)\end{array}$ \\
\hline Growth & $\begin{array}{l}0.0070 \\
(0.0058)\end{array}$ & $\begin{array}{l}0.0060^{*} \\
(0.0032)\end{array}$ & $\begin{array}{l}0.0080 \\
(0.0053)\end{array}$ & $\begin{array}{l}0.0040 \\
(0.0034)\end{array}$ & $\begin{array}{l}0.0044 \\
(0.0087)\end{array}$ & $\begin{array}{l}0.0129 \\
(0.0081)\end{array}$ \\
\hline GDP & $\begin{array}{l}-0.2146^{* *} \\
(0.1034)\end{array}$ & $\begin{array}{l}-0.1119^{* *} \\
(0.0363)\end{array}$ & $\begin{array}{l}-0.1056 \\
\text { (0.0997) }\end{array}$ & $\begin{array}{l}-0.0877 \\
(0.0594)\end{array}$ & $\begin{array}{l}-0.5585^{* * *} \\
(0.1440)\end{array}$ & $\begin{array}{l}-0.2537^{*} \\
(0.1314)\end{array}$ \\
\hline Divorce & $\begin{array}{l}-0.0064 \\
(0.2145)\end{array}$ & $\begin{array}{l}0.1473^{* * *} \\
(0.0293)\end{array}$ & $\begin{array}{l}0.2524 \\
(0.2054)\end{array}$ & $\begin{array}{l}0.1394^{* * *} \\
(0.0399)\end{array}$ & $\begin{array}{l}-0.7213^{* *} \\
(0.3014)\end{array}$ & $\begin{array}{l}0.1748^{*} \\
(0.0835)\end{array}$ \\
\hline Alcohol & $\begin{array}{l}-0.2210 \\
(0.2096)\end{array}$ & $\begin{array}{l}0.3285^{* *} \\
(0.1232)\end{array}$ & $\begin{array}{l}-0.2967 \\
(0.2088)\end{array}$ & $\begin{array}{l}-0.3116 \\
(0.2120)\end{array}$ & $\begin{array}{l}0.1437 \\
(0.2921)\end{array}$ & $\begin{array}{l}0.2632^{* * *} \\
(0.0833)\end{array}$ \\
\hline Fertility & $\begin{array}{l}-0.0496 \\
(0.4552)\end{array}$ & $\begin{array}{l}0.0288 \\
(0.0981)\end{array}$ & $\begin{array}{l}0.2533 \\
(0.4026)\end{array}$ & $\begin{array}{l}-0.1355 \\
(0.1154)\end{array}$ & $\begin{array}{l}-0.9600 \\
(0.7107)\end{array}$ & $\begin{array}{l}0.4616 \\
(0.2995)\end{array}$ \\
\hline Constant & $\begin{array}{l}3.6548^{* * *} \\
(1.0356)\end{array}$ & $\begin{array}{l}2.3132^{* * *} \\
(0.5816)\end{array}$ & $\begin{array}{l}2.7498 * * \\
(1.0901)\end{array}$ & $\begin{array}{l}4.0029^{* * *} \\
(1.0854)\end{array}$ & $\begin{array}{l}6.7732^{* * *} \\
(1.3890)\end{array}$ & $\begin{array}{l}-1.6434 \\
(2.4079)\end{array}$ \\
\hline Observations & 37 & 16 & 37 & 16 & 37 & 16 \\
\hline $\mathrm{R}^{2}$ & 0.652 & 0.942 & 0.553 & 0.931 & 0.855 & 0.950 \\
\hline $\mathrm{R}^{2}$ adjusted & 0.569 & 0.892 & 0.445 & 0.871 & 0.820 & 0.906 \\
\hline F-statistic & 10.12 & 330.8 & 10.50 & 205.4 & 45.84 & 453.8 \\
\hline
\end{tabular}

Note: Heteroscedasticity and autocorrelation (HAC) adjusted standard errors in parentheses. $* * * p<0.01$, $* * \mathrm{p}<0.05, * \mathrm{p}<0.1$ 